\title{
Agronomical and phytochemical aspects of fafia
}

\author{
Gisele F Vilela ${ }^{1}$; Lin C Ming ${ }^{1}$; Márcia OM Marques²; Sandra MP da Silva ${ }^{3}$; ́́lio Montanari Junior ${ }^{4}$ \\ ${ }^{1}$ UNESP-FCA, Depto. Produção Vegetal, C. Postal 237, 18603-970 Botucatu-SP; gisavilela1@gmail.com; ${ }^{2}$ IAC-Campinas, Centro de \\ Pesquisa e Desenvolvimento de Recursos Genéticos Vegetais, C. Postal 28, Guanabara, 13012-970 Campinas-SP; ${ }^{3}$ APTA-SAA, Pólo do \\ Vale do Paraíba, C. Postal 32, 12400-970 Pindamonhangaba-SP; ${ }^{4}$ UNICAMP-CPQBA, C. Postal 6171, 13081-970 Campinas-SP
}

\begin{abstract}
The medicinal species fafia (Hebanthe eriantha), is a product of extractivism in the region of the Paraiba Valley, São Paulo state, Brazil, with endangered genetic variability. This study did an agronomical characterization and an analysis of active compounds of five accessions. This research is a partnership of UNESP-Botucatu Medicinal Plants Laboratory, Paraiba Valley Center (APTA) and CPQBA-UNICAMP Agrotechnological Division. A field experiment using completely random blocks with five accessions and seven replications was used. The stem and leaf wet/dry weights, root wet/ dry weight, length of the longest stem, foliar area, foam index and pfaffic acid content samples were evaluated. Accession I1800 had root dry weight, stem and leaf dry weight, and foliar area greater than other accessions (176.16 g/plant, $7.301 \mathrm{~kg} /$ plant, $\left.155.04 \mathrm{~cm}^{2}\right)$. Pfaffic acid content was similar to other accessions $\left(0.640-0.366 \% \mathrm{~mm}^{-1}\right)$ Among all five accessions, there is a positive correlation among the foliar area and stem and leaf dry weight and between the foliar area and root dry weight.
\end{abstract}

Keywords: Hebanthe eriantha, medicinal plants, cultivation, pfaffic acid, Amaranthaceae.

\section{RESUMO}

\section{Aspectos fitotécnicos e fitoquímicos de acessos de fáfia}

A espécie medicinal fáfia (Hebanthe eriantha), é um recurso extrativista da região do Vale do Paraíba, cuja variabilidade genética encontra-se ameaçada. Neste estudo realizou-se a caracterização agronômica e análise de princípio ativo de cinco acessos. Este estudo é uma parceria entre o Laboratório de Plantas Medicinais da UNESP-Botucatu, o Pólo Vale do Paraíba em Pindamonhangaba da Agência Paulista de Tecnologia dos Agronegócios (APTA) e a Divisão de Agrotecnologia do Centro Pluridisciplinar de Pesquisas Químicas Biológicas e Agrícolas (CPQBA) da UNICAMP. Foi instalado um ensaio experimental a campo em blocos casualizados com cinco acessos e sete repetições. Foram avaliadas a massa fresca e seca da parte aérea, a massa fresca e seca da raiz, o comprimento da maior haste, a área foliar, o índice de espuma e o teor de ácido fáfico das amostras. O acesso $\mathrm{I} 1800$ apresentou uma massa seca de raiz, massa seca da parte aérea e área foliar superior aos demais acessos $(176,16$ $\mathrm{g} /$ planta, 7,301 kg/planta, $\left.155,04 \mathrm{~cm}^{2}\right)$. O teor de ácido fáfico não diferiu entre os acessos $(0,640-0,366 \% / \mathrm{mm})$ Existe uma correlação positiva entre área foliar e massa seca da parte aérea e entre área foliar e massa seca de raízes entre os cinco acessos.

Palavras-chave: Hebanthe eriantha, plantas medicinais, cultivo, ácido fáfico, Amaranthaceae.

\section{(Recebido para publicação em 27 de setembro de 2011; aceito em 21 de dezembro de 2012)} (Received on September 27, 2011; accepted on December 21, 2012)

$\mathrm{T}^{\mathrm{s}}$ he fafia (Hebanthe eriantha) has been described as the most important product of extractivism in the region of the Paraiba Valley, São Paulo state, Brazil. Silva et al. (2007) also verified that extractivism has been causing the species decrease and endangerment in the region.

Hebanthe eriantha, Amaranthaceae family, is a medicinal plant from the Brazilian Atlantic Rain Forest and it is native to all Brazilian regions. Previously named Pfaffia paniculata, in Borsch \& Pederson (1997) it was renamed to its old botanic name and classified in the genus Hebanthe. More recently, with the review of the Pfaffia and Hebanthe genera, the species was named
Hebanthe eriantha (Marchioretto, 2008). Hebanthe eriantha popular name is fáfia, ginseng-brasileiro, picão-detropeiro, solidonia, suma, cipó-suma and also corango-açu in the south of Brasil (Smith \& Downs, 1972; Marchioretto, 2008). Another species that has similar uses of Hebanthe eriantha and also named ginseng-brasileiro and fáfia, the Pfaffia glomerata, didn't change it denomination with the genus review.

Traditionally used in indigenous medicine, fafia is now recognized by its anticancer and stimulating properties. Its roots have triterpenic saponins, and the nortriterpenoid compounds, associated pfaffic acid and pfaffosides, showed inhibiting effect in tumor cell culture (Nakai et al., 1984). Besides these compounds, the roots also contain alantoin, sitosterol and stigmasterol (Takemoto, 1983; Nishimoto et al., 1984). In traditional communities in the Paraiba Valley, $H$. eriantha is used to control cholesterol (Barros, 2007).

Many studies showed fafia extracts antitumoral effect of several cell types, but few investigated extracts action mechanism. Another study, also hereafter described, investigated plant roots extract toxicity and its sexual performance stimulate effect.

Alcoholic extract demonstrated analgesic and antiinflammatory effect of rats edema and low acute toxicity (Mazzanti \& Braghiroli, 1994). Silva 
et al. (2005) studied anticarcinogenic effects of fafia roots extracts and verified its hepatocarcinogenic inhibitor effect in rats and Carneiro et al. (2007) demonstrated fafia extract antiangiogenesis effect in rats. Roots extract produced inhibitor effect of Ehrlich tumor and its ascitic form and also had antiinflamatory effect with no toxic effect in rats (Matsuzaki et al., 2003; Matsuzaki et al., 2006).

Pinello et al. (2006) investigated the effect cause of Ehrlich tumor by fafia extract and related the increment of macrophages activity being a possible cause of antitumoral action. The antitumoral mechanism action was investigated by Ballas (2000) that found the hidration quality of sick cells by fafia roots extract that could be a possible cause.

Arletti et al. (1999) demonstrated stimulated sexual qualities of fafia extract in rats. The extract also increased sexual hormones level (estradiol, progesterone and testosterone) in rats without adverse effects (Oshima \& Gu, 2003).

Patent was granted for fafia extract use for falciform anemy treatment and also for aphrodisiac action, and plant extract was the component of a proprietary compound (Corrêa Junior, 2003).

The present study aimed to study fafia evaluating the vegetal characteristics, root production, and saponin and pfaffic acid quantification of different species populations intended to establish the bases for the cultivation of the species and cooperating with the regional production development of the species.

\section{MATERIAL AND METHODS}

Initially, a collection of thirty nine accessions collected from Paraiba Valley region, São Paulo state, Brazil was installed and added in Chemical, Biological and Agricultural Pluridisciplinary Research Center of the State University of Campinas (CPQBA) of Unicamp species germplasm collection. For the present study, five accessions from that collection were used. These five accessions were selected for this study because they showed the best results of seedling. Seed reproduction of Hebanthe eriantha is impracticable and rizome reprodution didn't offer all needed seedlings, therefore, cutting reproduction was the better option. Two accessions were collected from Paraiba Valley (G23 and G42) and another three accessions (I1800, I565 and I1801) were collected by the researcher Ílio Montanari Jr. in Nazaré Paulista (SP), Monte Verde (SP) and Rio de Janeiro (RJ), respectively.

Propagation of cuttings was carried out in a greenhouse with a $50 \%$ shading screen and microaspersion irrigation. Cuttings with three until five shoots and 14 to $18 \mathrm{~cm}$ of length were cut of plant stems conform shrub cuttings production recommended by Hartmann \& Kester (1990). Stem cuttings were applied in powder 20\% ANA (naphthalene acetic acid/Nafusako 20). Soon afterwards took place the planting in plastic tubets $(13,5 \times 3,5 \mathrm{~cm})$ containing Gioplant $^{\mathbb{B}}$ substratum. Seedlings were planted in the soil after three months.

The experiment was a combination of five accessions and seven replications in a completely random block design, and it was carried out at the experimental area of CPQBA. There were six plants per plots, with four central useful plants. The plant spacing was $2,0 \mathrm{~m}$ and each plant used area was $9,45 \mathrm{~m}^{2}$. Blocks $\mathrm{A}, \mathrm{B}, \mathrm{C}, \mathrm{D}$ and $\mathrm{E}$ were installed on December $11^{\text {th }}, 2007$, and blocks F and G were installed on January $15^{\text {th }}, 2008$. At planting time, organic fertilization using $250 \mathrm{~g}$ of Provaso $^{\circledR}$ compost per plant was done to improve soil physical structure, while its chemical analyses showed adequate essential nutrients levels. Provaso ${ }^{\circledR}$ compost had $15 \%$ of organic carbon, $\mathrm{C} / \mathrm{N}$ relation of $18 / 1$, $1 \%$ of nitrogen, $\mathrm{pH}$ of $6, \mathrm{CTC}$ of 300 , $\mathrm{CTC} / \mathrm{C}$ relation of 20 and $45 \%$ of humidity.

The harvest of six blocks began when plants were 16 months old, and the another block was harvested at 17 months.

The length of the longest stem of the plants measurement was taken from the plant base until the last bud of the longest stem.

The foliar area was taken from five leaves from the plant base following Araújo (2007). This measurement was taken from one plant per plot. The foliar area was measured using a LI-COR 3100 digital equipment with direct reading in $\mathrm{cm}^{2}$.

To obtain aerial part weighing, fresh harvested aerial part was put in nylon screened bags, weighed and after placed in a drying cabinet for the drying. The drying cabinet was set under constant temperature at $45^{\circ} \mathrm{C}$ using a forced ventilation system (Falkenberg et al., 2003). After the drying, the material with 6 to $8 \%$ of humidity was weighed again.

The collected roots were washed under a water jet to clean the soil on them. After the washing, the roots were weighed and ground in a food processor. Then, the roots were put in a drying cabinet for 24 hours to dry, after they were weighed again (Sonaglio et al., 2003; Falkenberg et al., 2003).

The saponins were determined by the Foam Index described by Costa (1982). $0,5 \mathrm{~g}$ of ground root was weighed, 100 $\mathrm{mL}$ of distilled water was added and then it was boiled for five minutes. After cooling, the extract was filtered through cotton and the volume completed until $100 \mathrm{~mL}$. A series of ten dilutions was prepared in assay tubes, using 1 to 10 $\mathrm{mL}$ of extract per tube, and the volume was completed with distilled water until reaching $10 \mathrm{~mL}$. The tubes were shaken vertically for fifteen seconds and the samples were kept at rest for fifteen minutes. The foam index was determined based on the tube dilution where there was a $1-\mathrm{cm}$ persistent foam ring. The final calculation was made according to WHO (1992).

For the quantification of the total pfaffic acid present in fafia roots, a high-efficiency liquid cromatography technique combined with diode array detection and selective mass detection (LC-DAD-MS) was used, according to Souza (2011) methodology described.

Due to the commercial unavailability, the analytical standard of pfaffic acid was obtained in laboratory by a fractional and purification process of fafia root extracts, previously submitted to acid hydrolysis. The identification of the isolated and purified compound 
was confirmed by RMN and mass spectrometry and the chromatographical purity was considered (Souza, 2011).

The samples were processed in a grinder and dried until they became a homogeneous powder; afterwards, the powder was submitted to extraction in hydroalcoholic means and to acid hydrolysis.

The hydrolyzed extract was submitted to an ethyl acetate reaction, then it was concentrated in a rota-evaporator and injected in the chromatography system. The chromatography analyses were done using an Alliance LC-DADMS Waters chromatography system equipped with a model 2996 photodiode array detector, a column warming oven, a selective mass detector model 3100, and an Empower software. The separation of the sample constituents was performed in a C-18 $100 \times 2,1 \mathrm{~mm}$ analytical column with $3-\mu \mathrm{m}$ particles, using methanol and water as eluent. The quantification was done at $215 \mathrm{~nm}$, confirming the selectivity of the mass detector method.

In the statistical analysis, average comparisons were analysed by Tukey's test at the 5\% probability level, using SAS program (1997).

\section{RESULTS AND DISCUSSION}

The accessions of this germplasm collection range from 0.40 to 1.0 meters of height, and they do not reach the height of $1.80 \mathrm{~m}$ related by Marchioretto (2008). Fafia is a climbing plant, so, the length of the longest stem of the plant doesn't mean its height, but its lateral expansion capacity. The harvested roots had a maximum diameter of $3 \mathrm{~cm}$ and they were very thin. Accession I1800 had the thickest roots.

According to the information given by one of the collectors (Mr. Jose Donizete da Silva) that helped collect the material and that has worked with the species for twenty-five years, fafia shows a physionomic type: it has big large oval leaves and thick yellowish roots that grow parallel to the soil. This is the most common type in the region. Accessions G23, G42 and I565 present this physionomic type. Accession I1800 is robust, has light green oval leaves and white roots, and I1801 is a small semierect type, little vigorous with reddish leaves and white roots.

Accession I1800 had a different aspect for its roots that differed from the other accessions. After harvested and cleaned, the roots became darker with little dark spots on them, and they turned grey after processed, differing from others found at commercial ones that is light yellow. The other accessions present typical species root coloring. The roots had sweet smell after processed and the changing color indicated an oxidation process. The roots were very fibrous.

About aerial part dry weight, accession I1800 showed the greatest aerial part dry weight of all accessions (Table 1 and Figure 1A). Accessions G42, I565, G23 and I1801 showed a similar aerial part dry weight. Accession 1800 aerial part dry weight average was four times greater than the average of the other accessions.

About root dry weight, accession I1800 showed the greatest root weight of all accessions (Table 1 and Figure 1B). Its average production by plant, of 176.16 g plant $^{-1}$ was $89.2 \%$ higher than the second one, accession G42 $(93.09 \mathrm{~g}$ plant $\left.^{-1}\right)$. Accessions G42, I565, G23 and I1801 showed similar root production, with production average of $93.09 ; 78.7$; 66.81 and $47.81 \mathrm{~g} /$ plant, respectively. The accessions were harvested at sixteen and seventeen months. The dried root production average of accession 1800 , considering the $2 \times 4-m$ spacing used in the experiment, is equivalent to a production of $220.2 \mathrm{~kg}$ of dried root ha $^{-1}$. The study by Montanari Junior (1999) determined the productivity of three clones of Pfaffia paniculata and verified that the clones Rio de Janeiro, Mogi das Cruzes and Nazaré Paulista produced $43.8 ; 52.4$ and $135.5 \mathrm{~g}$ of dried rootplant ${ }^{-1}$. A $1 \times 1-\mathrm{m}$ spacing was used and the harvest was done when the plants were fourteen months old. The results of Rio de Janeiro and Moji das Cruzes clones did not differ among themselves, but differed from Nazaré Paulista clone results. The Rio de Janeiro clone is accession I1801, and the clone Nazaré Paulista is accession I1800. In the present study, Nazaré Paulista clone showed greater averages, but it was lower than one related by Montanari Junior (1999).

For aerial part of biomass, accession I1800 also showed the greatest weight of all accessions (Table 1 and Figure 1A). Accessions G42, I565, G23 and I1801 showed a similar aerial part dry weight. The roots of accession I1800 have a different aspect from those ones that are commercialized by the collectors from the Paraiba Valley region. The commercialized roots have

Table 1. Average of agronomical and chemical data of five accessions of fafia (Hebanthe eriantha) [valores médios de resultados agronomicos e quimicos de fafia (Hebanthe eriantha)]. Botucatu, UNESP, 2009.

\begin{tabular}{lcccccc}
\hline Accessions & $\begin{array}{c}\text { Dry weight of aerial } \\
\text { part (kg/plant) }\end{array}$ & $\begin{array}{c}\text { Root dry weight } \\
(\mathbf{g} / \mathbf{p l a n t})\end{array}$ & $\begin{array}{c}\text { Length of the } \\
\text { longest stem }(\mathbf{c m})\end{array}$ & $\begin{array}{c}\text { Foliar área } \\
\left(\mathbf{c m}^{2}\right)\end{array}$ & $\begin{array}{c}\text { Saponin level } \\
(\text { foam index })\end{array}$ & $\begin{array}{c}\text { Total pfaffic acid } \\
\text { quantity }(\% / \mathbf{m m})\end{array}$ \\
\hline $\mathrm{I} 1800$ & $7.301 \mathrm{a}( \pm 3.97)$ & $176.16 \mathrm{a}( \pm 78.85)$ & $279.5 \mathrm{a}( \pm 45.46)$ & $155.040 \mathrm{a}$ & $181.31 \mathrm{ab}$ & $0.632 \mathrm{a}( \pm 0.12)$ \\
$\mathrm{G} 42$ & $1.666 \mathrm{~b}( \pm 0.82)$ & $93.09 \mathrm{~b}( \pm 49.25)$ & $172.5 \mathrm{c}( \pm 45.29)$ & $67.525 \mathrm{c}$ & $211.12 \mathrm{ab}$ & $0.366 \mathrm{a}( \pm 0.07)$ \\
$\mathrm{I} 565$ & $1.466 \mathrm{~b}( \pm 0.35)$ & $78.70 \mathrm{~b}( \pm 41.49)$ & $233.6 \mathrm{ab}( \pm 31.89)$ & $45.455 \mathrm{c}$ & $208.35 \mathrm{ab}$ & $0.520 \mathrm{a}$ \\
$\mathrm{G} 23$ & $1.102 \mathrm{~b}( \pm 0.34)$ & $66.81 \mathrm{~b}( \pm 32.09)$ & $203.9 \mathrm{bc}( \pm 54.54)$ & $57.620 \mathrm{c}$ & $256.67 \mathrm{a}$ & $0.570 \mathrm{a}( \pm 0.07)$ \\
$\mathrm{I} 1801$ & $0.870 \mathrm{~b}( \pm 0.48)$ & $47.81 \mathrm{~b}( \pm 23.99)$ & $110.7 \mathrm{~d}( \pm 24.04)$ & $105.104 \mathrm{~b}$ & $168.06 \mathrm{~b}$ & $0.640 \mathrm{a}( \pm 0.10)$ \\
\hline
\end{tabular}

Averages followed by the same letter in the column do not significantly differ in Tukey's test at $5 \%$ of probability (valores médios seguidos de mesma letra na coluna não diferem entre si, teste Tukey, 5\%). 


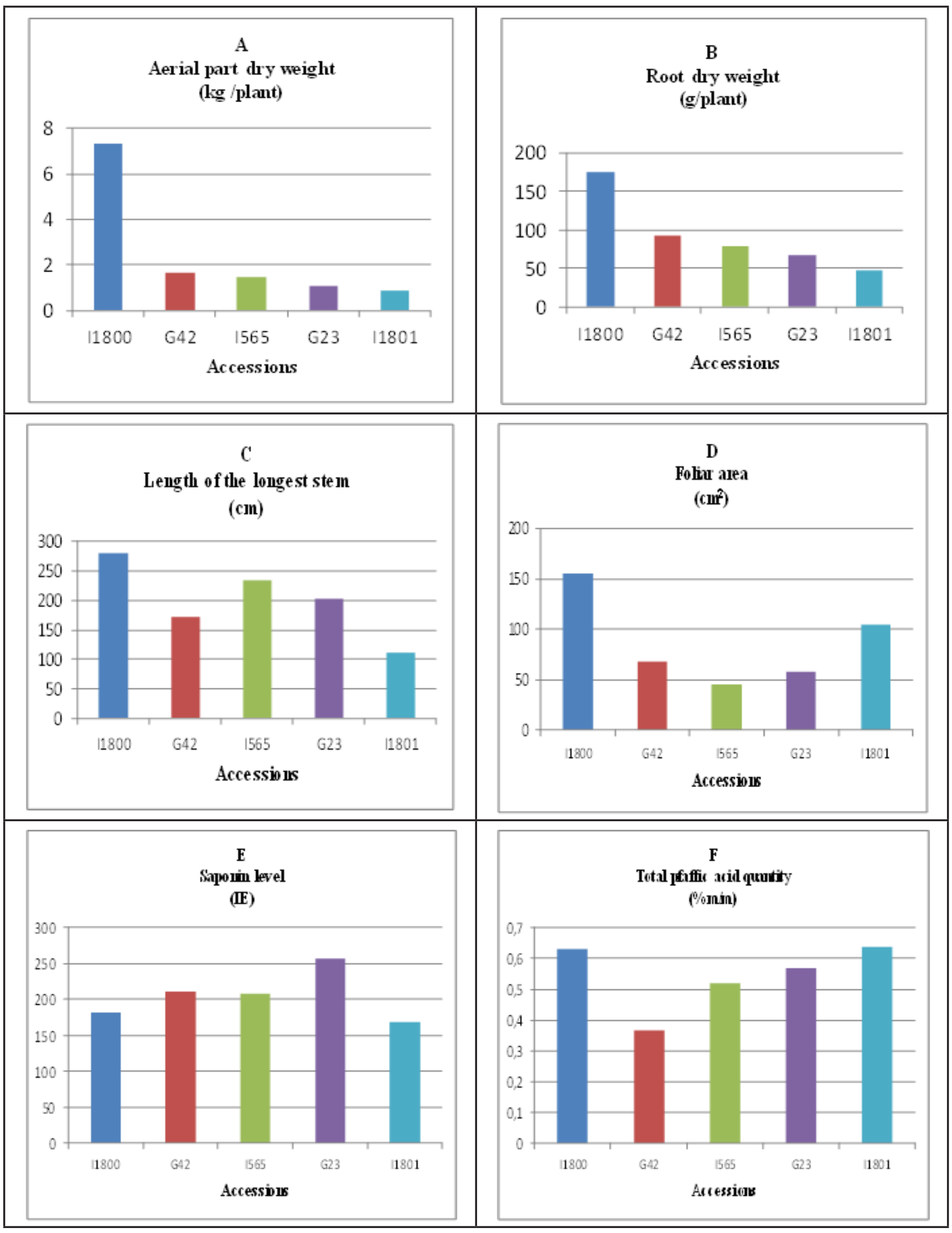

Figure 1. Agronomical and chemical data graphics of five accessions of fafia (Hebanthe eriantha) [(gráficos com dados agronomicos e quimicos de cinco acessos de fáfia (Hebanthe eriantha)]. Botucatu, UNESP, 2009. 
a yellowish color when turned into a powder. Accession I1800 plants have white roots that become grey when freshly ground. The powder also has a grayish color. The roots and the aerial part of accession I1800 are similar to another Hebanthe species, the Hebanthe pulverulenta whose roots become dark when processed and present vigorous aerial part, too. The difference of the two species is that $H$. pulverulenta has pulverulent trichomes and ramosoverticilado on branches, petiole and adaxial-abaxial leaves face, and for $H$. eriantha, abaxial face varies from subhairy to slightly hairy and trichomes are estrigosos, articulated (Marchioretto, 2008).

Accession I1800 showed the greatest average for stem length, $279.52 \mathrm{~cm}$ (Table 1 and Figure 1C), but did not differ from accession I565. This length of the longest stem can help to calculate the spacing and project the horizontal support, but there is no relation with biomass production of the aerial part, because accession I1800 produced five times more the dry weight of aerial part than accession I565. Accession I1801, besides having the shortest stem length, is a semi-climbing plant, like a small shrub when it is in the initial development.

For foliar area, accession I1800 showed the greatest foliar area of all accessions. Accession I1801 showed the second greatest foliar area and accessions G23, G42 and I565 did not differ (Table 1; Figure 1D). This occurred because accession I1800 and I1801 have oval to elliptical leaves, while the other accessions have elliptical to lanceolate leaves.

Regarding the vegetal characteristics, accession I1800 stands out because it shows the greatest aerial biomass production, the biggest stem length and foliar area when compared to the other accessions. Accessions G23, G42, I565 and I1801 have similar vegetal characteristics.

The results of the foam index indicated that accession G23 showed the greatest average $(\mathrm{IE}=256.67)$, differing statistically from accession I1801 that showed the smaller average (168.06). The other accessions didn't differ from accessions G23 and I1801 (Table 1; Figure 1E). The results differed from the ones obtained by Vigo et al. (2004) that used the same foam index method and obtained the index $500 \pm 0$ for fafia.

Regarding the total pfaffic acid quantities, (Table 1 and Figure 1F), the accessions did not show differences among themselves. The study by Nakai et al. (1984) in relation to the extraction and determination of compounds of Pfaffia paniculata showed $5 \mathrm{~g}$ of saponins in $2 \mathrm{~kg}$ of dried roots. This is an amount of $0.25 \%$ of saponins. However, there are not reference studies of pfaffic acid quantification for Hebanthe eriantha yet. As for the other plants that are related to fafia, for example, the Panax ginseng, the quantities of triterpenic saponins range from 0.5 to 3\% (Schenkel, 2003). For $\beta$-ecdisona, present in Pfaffia glomerata according to a study by Corrêa Junior (2003), an average quantity of $0.29 \%$ was obtained, but other studies reported obtained quantities ranging from $0.64 \%$ to $0.76 \%$.

The variables foliar area/root dry weight showed a Pearson's Correlation Coefficient (r) of 0.55 and 0.77 respectively and there was a significant positive correlation to the five accessions of fafia. There was also a significant correlation between aerial part weight/ root dry weight, showing a value of $\mathrm{r}=0,84$. There was not a significant correlation between the other variables.

Montanari Junior (2005) and Nascimento et al. (2007) also found a positive correlation between aerial part characteristics and roots production per plant of Pfaffia glomerata accessions. According to Montanari Junior (2005), it means that if roots are the interest, it's possible select good plants that showed good aerial development, and so, it's not necessary a destructive harvest of the plants.

The data from the aerial part dry weight and the length of the longest stem of the accessions indicated the best spacing for the species. A support for this species is important to reasonably exploit the agricultural area, because the stem length average is $279.5 \mathrm{~cm}$ in accession I1800, and $233.6 \mathrm{~cm}$ in accession I565. A 1.5-m inter-row spacing and $1,0-\mathrm{m}$ spacing between plants using horizontal support is recommended.

The species presents rusticity and a satisfactory vegetal development with low external inputs. Some plants showed root rotting. Accession I1800 that has a robust vegetal development presented signs of herbivory, but did not decrease production. Herbivory did not happen in other accessions. Although the plant presents rusticity, the species has fragile stems that can break easily during agricultural management.

The most adequate harvest time should be after 16 months which was the one used in this study, because some roots were still thin. Some plants that were harvested at 2 years of age and were not in the experiment, showed much thicker roots.

The root preparation must be made with fresh roots, when they still allow handling. After drying, the manipulation is not possible anymore because the roots have a lot of fibers, making chopping and grinding difficult. For chopping and grinding of a large quantity of material, the use of resistant and robust equipment is recommended.

The present study showed that for future studies of the species, a recommend of news propagation tests is interesting.

The results about dry weight of aerial part and length of the longer branch of the accesses give some indications over the best space for this species. The staking for the species is desirable for a rational use of agricultural area, since the length of the stems can reach on average 279.5 in 1800 and 233.6 in access 565. A spacing of 1.5 meters between rows and $1.0 \mathrm{~m}$ between plants with staking may be indicated.

\section{ACKNOWLEDGEMENTS}

We thank National Council for Scientific and Technological Development (CNPq) for the financial support of this study and the research fellowship; Chemical, Biological and Agricultural Pluridisciplinary Research Center of the State University of Campinas (CPQBA-UNICAMP) for providing the experimental area, seedling 
nursery and workers help; and Dra. Marili Villa Nova Rodrigues, researcher at the CPQBA Organic Chemical Laboratory for the collaboration on the pfaffic acid quantification analysis.

\section{REFERENCES}

ARAÚJO FP. 2007. Caracterização da variabilidade morfoagronômica de maracujazeiro (Passiflora cincinnata Mast.) no semi-árido brasileiro. Botucatu: UNESP/ FCA. 94p (Tese doutorado).

ARLETTI R; BENELLI A; CAVAZZUTI E; SCARPETTA G; BERTOLINI A. 1999. Stimulating property of Turnera diffusa and Pfaffia paniculata extracts on the sexual behavior of male rats. Psychopharmacology 143: 15-19.

BALLAS SK. 2000. Hydration of sickle erythrocytes using a herbal extract (Pfaffia paniculata) in vitro. British Journal of Haematology 111: 359-362.

BARROS LCP. 2007. Conhecimento sobre plantas medicinais com atividade de controle do colesterol, pressão arterial e problemas renais, utilizadas pela população residente no bairro dos Marins, município de Piquete$S P$. Botucatu: UNESP/FCA. 166p (Tese mestrado)

BORSCH T; PEDERSON MT. 1997. Restoring the generic rank of Hebanthe Martius (Amaranthaceae). Sendtnera 4: 13-31.

CARNEIRO CS; PINTO FAC; SILVA TC; MATSUZAKI P; AKISUE G; HARAGUCHI M; GORNIAK SL; DAGLI MLZ. 2007. Pfaffia paniculata (Brazilian ginseng) methanolic extract reduces angiogenesis in mice. Experimental and Toxicologic Pathology 58: 427-431

CORRÊA JUNIOR C. 2003. Estudo agronômico de Pfaffia glomerata (Spreng.) Pedersen: sazonalidade na produção de raízes e conteúdos de ecdisona em diferentes acessos de São Paulo, Paraná e Mato Grosso do Sul. 2003. Botucatu: UNESP/FCA. 94p (Tese doutorado).

COSTAAF. 1982. Farmacognosia: farmacognosia experimental. 2. ed. Lisboa: Fundação Calouste Gulbenkian, v. 3, 1032 p.

FALKENBERG MB; SANTOS RI; SIMÕES CMO. 2003. Introdução à análise fitoquímica. In: SIMÕES CMO; SCHENKEL EP; GOSMANN G; MELLO JCP; MENTZ LA; PETROVICK PR (orgs). Farmacognosia: da planta ao medicamento. 5. ed. Porto Alegre:
UFRGS; Florianópolis: UFSC, p. 230-288.

HARTMANN HT; KESTER DE. 1990. Plant propagation: principles and practices. $6^{\text {th }} \mathrm{ed}$. New Jersey: Prentice Hall, 770p.

MARCHIORETTO MS. 2008. Os gêneros Hebanthe Mart. e Pfaffia Mart. (Amaranthaceae) no Brasil. 2008. Porto Alegre: UFRGS/Instituto de Biociências, 255p (Tese doutorado)

MATSUZAKI P; AKISUE G; OLORIS SCS; GORNIAK SL; ZAIDAN DAGLI ML. 2003. Effect of Pfaffia paniculata (Brazilian ginseng) on the Ehrlich tumor in its ascitic form. Life Sciences 74: 573-579.

MATSUZAKI P; HARAGUCHIB M; AKISUEC G; OLORISA SCS; NAGAMINEA MK; SILVA TC; SAKAIA M; FONSECA ESM; PALERMO-NETO J; GÓRNIAKA SL; DAGLIA MLZ. 2006. Antineoplastic effects of butanolic residue of Pfaffia paniculata. Cancer Letters 238: 85-89.

MAZZANTI G; BRAGHIROLI L. 1994. Analgesic antiinflammatory action of Pfaffia paniculata (Martius) Kuntze. Phytotherapy Research 8: 413-416.

MONTANARI JÚNIOR I. 1999. Produtividade de três clones de Pfaffia paniculata (Mart.) O. Kuntze. In: JORNADA PAULISTA DE PLANTAS MEDICINAIS, 4. Caderno de resumos... Ribeirão Preto: UNAERP, p. 30-32.

MONTANARI JÚNIOR I. 2005. Avaliação de genótipos de Pfaffia glomerata (Spreng.) Pedersen visando seu cultivo comercial. Campinas: IAC. 75p (Tese mestrado).

NAKAI S; TAKAGI N; MIICHI H; HAYASHI S; NISHIMOTO N; TAKEMOTO T; KIZU H. 1984. Pfaffosides, nortriterpenoid saponins, from Pfaffia paniculata. Phytochemistry 23: 1703-1705.

NASCIMENTO EX; MOTA JH; VIEIRA MC; ZÁRATE NAH. 2007. Produção de biomassa de Pfaffia glomerata (Spreng.) Pedersen e Plantago major L. em cultivo solteiro e consorciado. Ciência e Agrotecnologia 31: 724-730.

NISHIMOTO N; NAKAI S; TAKAGI N; HAYASHI S; TAKEMOTO T; ODASHIMA S; KIZU H; WADA Y. 1984. Pfaffosides and nortriterpenoid saponins from Pfaffia paniculata. Phytochemistry 23: 139-142.

OSHIMA M; GU Y. 2003. Pfaffia paniculata induced changes in plasma estradiol-17beta, progesterone and testosterone levels in mice. Journal of Reproduction and Development 49: $175-180$.

PINELLO KC; FONSECA EDE S; AKISUE
G; SILVA AP; SALGADO OLORIS SC; SAKAI M; MATSUZAKI P; NAGAMINE MK; PALERMO NETO J; DAGLI ML. 2006. Effects of Pfaffia paniculata (Brazilian ginseng) extract on macrophage activity. Life Sciences 78: 1287-1292.

SCHENKEL EP; GOSMANN G; ATHAYDE ML. 2003. Saponinas. In: SIMÕES CMO; SCHENKEL EP; GOSMANN G; MELLO JCP; MENTZ LA; PETROVICK PR (orgs). Farmacognosia: da planta ao medicamento. 5. ed. Porto Alegre: UFRGS; Florianópolis: UFSC, p. 711-741.

SILVA SMP; BLANCO MCSG; MING LC; CARVALHO I; COSTA MAG; SOUZA MMS. 2007. Diagnóstico sobre a cadeia produtiva de plantas medicinais, aromáticas e condimentares na Região do Vale do Paraíba, SP. In: JORNADA PAULISTA DE PLANTAS MEDICINAIS, 8. Jornal Brasileiro de Fitomedicina. São Paulo: EDIC Editores Científicos, v. 5, p. 108.

SILVA TC; SILVA AP; AKISUEB G; AVANZO JL; NAGAMINEA MK; FUKUMASUA H; MATSUZAKIA P; RASPANTINIC PC; HARAGUCHID M; GÓRNIAKA SL; DAGLIA MLZ. 2005. Inhibitory effects of Pfaffia paniculata (Brazilian ginseng) on preneoplastic and neoplastic lesions in a mouse hepatocarcinogenesis model. Cancer Letters 226: 107-113.

SMITH LB; DOWNS RJ. 1972. Amarantáceas. In: REITZ R. Flora ilustrada catarinense. Itajaí: Herbário Barbosa Rodrigues, parte 1, p. 37-40.

SONAGLIO D; ORTEGA GG; PETROVICK PR; BASSANI VL. 2003. Desenvolvimento tecnológico e produção de fitoterápicos. In: SIMÕES CMO; SCHENKELEP; GOSMANN G; MELLO JCP; MENTZ LA; PETROVICK PR (orgs). Farmacognosia: da planta ao medicamento. 5. ed. Porto Alegre: UFRGS; Florianópolis: UFSC, p. 290-324.

SOUZA KP. 2011. Desenvolvimento e validação de método analítico para quantificação de ácido pfáffico em Hebanthe eriantha. Campinas: UNICAMP. 98p (Tese mestrado).

TAKEMOTO T. 1983. Pfaffic acid, a novel nortriterpene from Pfaffia paniculata Kuntze. Tetrahedron Letters 24: 1057-1060.

VIGOCLS; NARITAE; MILANEZE-GUTIERRE MA; MARQUES LC. 2004. Caracterização farmacognóstica comparativa de Pfaffia glomerata (Spreng) Pedersen e Hebanthe paniculata Martius - Amaranthaceae. Revista Brasileira de Plantas Medicinais 6: 7-19.

(WHO) WORLD HEALTH ORGANIZATION. 1992. Quality control methods foi medicinal plant materials. Geneva: $115 \mathrm{p}$. 